\title{
SODIUM AND POTASSIUM INTAKE IN HUNGARIAN CHILDREN AND ADOLESCENTS: COMPARISON OF TWO CROSS SECTIONAL STUDIES
}

\author{
O. Lakatos*, Zs. Györke and E. Sulyok \\ Institute of Public Health and Health Promotion, Faculty of Health Sciences, \\ University of Pécs, H-7621 Pécs, Vörösmarty utca 4. Hungary
}

(Received: 15 October 2013; accepted: 23 January 2014)

\begin{abstract}
The purpose of the study was to assess the sodium and potassium intake among Hungarian children and adolescents. The study was undertaken to estimate daily sodium and potassium intake by measuring 24-h urinary electrolyte excretion rate in 200 Hungarian children (age 1-18 years). Daily sodium and potassium intake positively correlated with age, body mass index, and systolic blood pressure. As a result of the parallel trend and time course of urinary sodium and potassium excretion the sodium to potassium ratio, the important risk factor for essential hypertension remained practically unchanged with age. We did not find a significant difference in this ratio between hypertensive and normotensive, or obese and non-obese children. Sodium and potassium intake expressed per kilogram body weight decreased steadily with age, but there was no significant difference between boys and girls. When adjustment was made for age and body mass index, using multivariate regression analysis, the systolic blood pressure proved to be independent of urinary sodium excretion and daily potassium intake. Compared with Dietary Reference Intake values, the present study demonstrates that, on average, Hungarian children and adolescents have a diet rich in sodium, and poor in potassium, although during the last 20 years a favourable trend can be detected. intake

Keywords: children and adolescents, blood pressure, potassium intake, Dietary Reference Intakes, sodium
\end{abstract}

High salt intake has a strong association with greater risk of hypertension, stroke, and other cardiovascular diseases (STRAzZULO et al., 2009). The prevalence of cardiovascular morbidity and mortality is excessively high in Hungary. When compared to other countries of the European Union, mortality due to hypertension, arteriosclerosis, and related diseases is twice as high as the European average, and accounts for $48.9 \%$ of overall mortality (D.M.D.B., 2011). Primary hypertension has been shown to be the result of genetic and multiple environmental factors and among the latter dietary salt intake has been claimed to play a prominent role (FroHLICH, 2007). Moreover, reduction in dietary sodium intake has been proved to lower blood pressure both in normotensive subjects and in patients with hypertension (SACKS et al., 2001; Kesteloot et al., 2011). It is of further note that the effects of dietary sodium intake on blood pressure elevation can be attenuated or enhanced by a diet high or low in potassium, respectively (SACKS et al., 2001). As several studies have suggested, the sodium to potassium ratio represents a more important risk factor for hypertension and cardiovascular disease than each factor alone (YANG et al., 2011).

Convincing evidence indicates that adult primary hypertension may originate in childhood, and that salt preference later in life may be influenced by salt intake in infancy and childhood (SHIRAZKI et al., 2007; Brion et al., 2008). Infancy and early childhood has been

\footnotetext{
* To whom correspondence should be addressed.

Phone/Fax: +36-72-513-670; e-mail: orsolyalakatos@freemail.hu.
} 
shown to be an especially sensitive period concerning the effect of sodium intake on blood pressure (GELEIJNSE et al., 1997; BRION et al., 2008). Studies in children have also shown that lowering salt intake induced a significant reduction in blood pressure (ElLison et al., 1989; YANG et al., 2012). While it seems clear that sodium impacts blood pressure in children, its effects may be enhanced by other factors including obesity and increasing age (HANEVOLD, 2013).

The Hungarian children and adolescents are consuming much more than the recommended amount of sodium. A survey of the 2005-2006-school year in the Hungarian capital, Budapest, shows that the average salt intake of elementary and middle school boys and girls is about 2.5 times of the recommended value (BIRó et al., 2007). According to a study of Hungarian 3-5-year-old children in 2009, the daily salt content of the food provided by food caterers in kindergartens adds up to $6.9 \pm 1.9$ grams (range: 3,8-11,0 grams/die) (MARTOS, 2010).

Limited data are available on sodium and potassium intake in children estimated by 24hour excretion in urine (KRISTBJORNSDOTTIR et al., 2012). However, measurement of electrolyte excretion in 24-hour urine is regarded as a gold standard, for defining daily sodium and potassium intake (ReINIVUo et al., 2006).

In the present study, an attempt was made to compare sodium and potassium intake with the most detailed and age-specific Dietary Reference Intakes (DRI) (USDA, 2009), to assess the relationship between the intake of these electrolytes and blood pressure with or without adjustment for age, gender, and body mass index (BMI), to detect possible changes in electrolyte consumption, and to compare the current results with the data from a previous study, undertaken in the same hospital, in 1990 (GYÖRKE, 1990).

\section{Materials and methods}

Two hundred children (100 girls and 100 boys), between ages of 1 and 18 years, were enrolled in the study. The children were admitted to the County Children's Hospital in Pécs, from South-West Hungary, between November 2008 and January 2010. The reason for admission was elective surgery and / or routine clinical examination. Neither of them had clinical or laboratory evidence of renal, cardiac, or endocrine diseases, secondary hypertension, or disturbances of electrolyte and acid-base status. They consumed traditional Hungarian food, without any dietary restriction. None were prescribed medication affecting renal function or blood pressure prior to or during the study.

Anthropometric parameters were obtained by trained technicians using standard methods (GiBson, 2005). Subjects wore one layer of undergarments and no shoes. Body height was measured to the nearest $0.1 \mathrm{~cm}$ using a calibrated measuring instrument (Harpenden Stadiometer, Crymych, United Kingdom), and body weight was measured to the nearest $0.1 \mathrm{~kg}$ using a validated electronic scale (Seca 899, Birmingham, United Kingdom). BMI was calculated as body weight in kilograms, divided by height in meters squared $\left(\mathrm{kg} \mathrm{m}^{-2}\right)$. Children were considered to be obese when their BMI exceeded the 95 percentile value of age and gender matched controls (JouBERT et al., 2006). Blood pressure (BP) was measured on the left arm after a rest period of $5 \mathrm{~min}$. Three measurements were undertaken by welltrained personnel using an automatic oscillometric device (Omron MX3, Omron Matsusaka, Japan), with appropriate cuffs for the upper arm size of the patients. Mean values of systolic and diastolic BP were calculated from these three measurements. The child was considered 
hypertensive when his systolic and/or diastolic BP exceeded the 95 percentile for age, gender, and height percentiles matched controls (N.H.B.P.E.P., 2004).

We assumed that a single 24-h urine collection would provide a reliable estimate of daily sodium and potassium intake (ReInIVuo et al., 2006). Timed urine samples were obtained over a 24-h period, after discarding urine voided immediately before the collection period. The toddlers, who were still in diapers, received special collection bags, with an adhesive at one end. The collected urine was kept at 4 degrees Celsius until used. Urine collection was regarded adequate with urine production of 1 to $3 \mathrm{ml} \mathrm{kg}^{-1} \mathrm{~h}^{-1}$. The sodium and potassium concentrations of native urine were measured by ion selective electrodes (Cobas Integra 400 Chemistry Analyzer, Roche, Basel, Switzerland). Under constant circumstances 24-h urinary excretion of sodium was considered to be equivalent to daily sodium intake (OVESEN \& BoEING, 2002), whereas according to a recent recommendation (TASEVSKA et al., 2006), daily potassium intake was calculated accepting that urinary potassium excretion amounts to only $77 \%$ of dietary intake. In our paper this corrected potassium value is used. Based on the laboratory results, we calculated sodium and potassium intake, sodium and potassium excretion per kilogram $(\mathrm{kg})$ body weight, and sodium to potassium ratio in every age group. To ease the comparison of the values from children with different ages and body weights, it might be convenient to use the per kg approach (KRISTBJORNSDOTTIR et al., 2012).

The study, completed in 1990, was undertaken to estimate daily sodium intake by measuring urinary electrolyte excretion in 203 healthy Hungarian children, ages $0-17$ years (GYÖRKE, 1990). The urine was collected over a 24-h period. The electrolyte concentration of native urine was measured by flame photometry (FLAPHO-4, Carl Zeiss, Jena, Germany). We compared the corrected sodium and potassium intake and sodium to potassium ratio measured in 2008-2010 to those of 1990.

Statistical analysis was prepared with SPSS v. 16 statistical computer software. For statistical evaluation Student's unpaired $t$-test, linear regression analysis, and when adjustments for confounding variables so required, multivariate regression analysis were used. Data were expressed as mean \pm SD. P values $<0.05$ were considered statistically significant.

For 24-h urine collection, informed parental consent and approval from the Institutional Ethics Committee were obtained.

\section{Results and discussion}

Among the 200 Hungarian children we found 32 hypertensive (16\%) and 42 obese $(21 \%)$ patients. The detailed characteristics of the sample are shown in the Table 1.

Table 1. Characteristics of the sample by age group (BMI, systolic and diastolic blood pressure)

\begin{tabular}{lcccc}
\hline $\begin{array}{l}\text { Age groups } \\
\text { (years) }\end{array}$ & Number of cases & $\begin{array}{c}\text { BMI }\left(\mathrm{kg} \mathrm{m}^{-2}\right) \\
\text { mean } \pm \text { SD }\end{array}$ & $\begin{array}{c}\text { SBP (Hgmm) } \\
\text { mean } \pm \text { SD }\end{array}$ & $\begin{array}{c}\text { DBP }(\mathrm{Hgmm}) \\
\text { mean } \pm \text { SD }\end{array}$ \\
\hline $1-3$ & 7 & $14.6 \pm 1.0$ & $98.0 \pm 7.7$ & $64.6 \pm 3.1$ \\
$4-8$ & 77 & $16.1 \pm 2.9$ & $104.8 \pm 9.0$ & $64.7 \pm 6.4$ \\
$9-13$ & 62 & $20.9 \pm 5.0$ & $117.6 \pm 11.1$ & $71.5 \pm 8.1$ \\
$14-18$ & 54 & $24.4 \pm 5.7$ & $127.3 \pm 12.5$ & $72.5 \pm 7.5$ \\
\hline
\end{tabular}


The daily sodium intake was found to have significant positive correlation with age, BMI, and systolic blood pressure (Fig. 1).

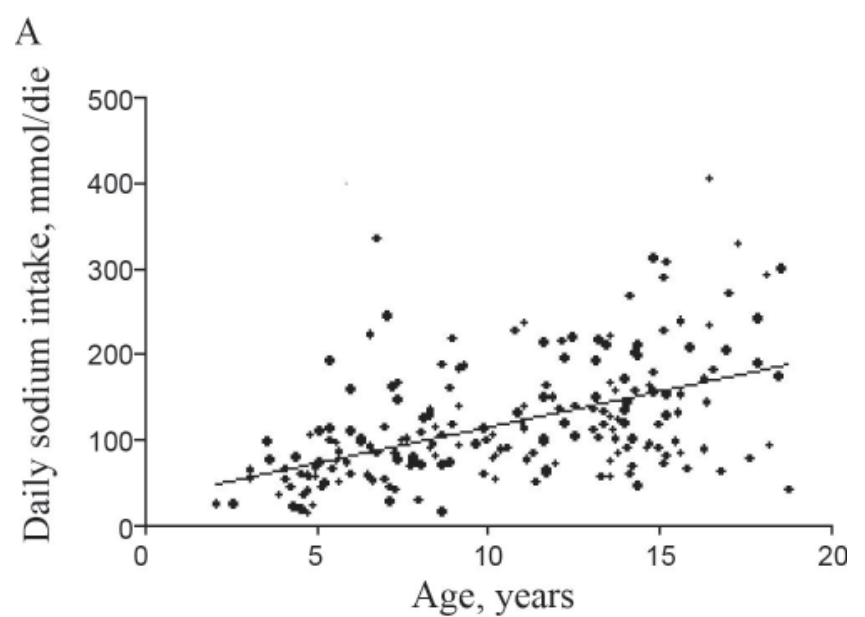

Fig. 1A. Daily sodium intake with advancing age (n: $200, \mathrm{r}^{2}=0.252,95 \% \mathrm{CI}: 6.355$ to $10.37, \mathrm{P}<0.0001$ )

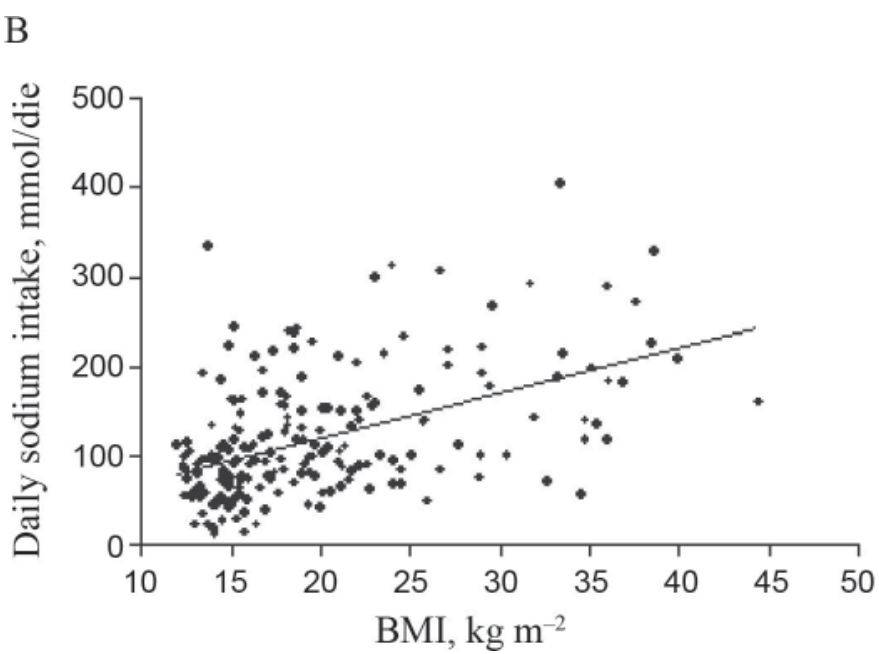

Fig. 1B. Linear regression analysis of daily sodium intake and body mass index (n: $200, \mathrm{r}^{2}=0.236,95 \% \mathrm{CI}: 3.735$ to $6.244, \mathrm{P}<0.0001$ ). 


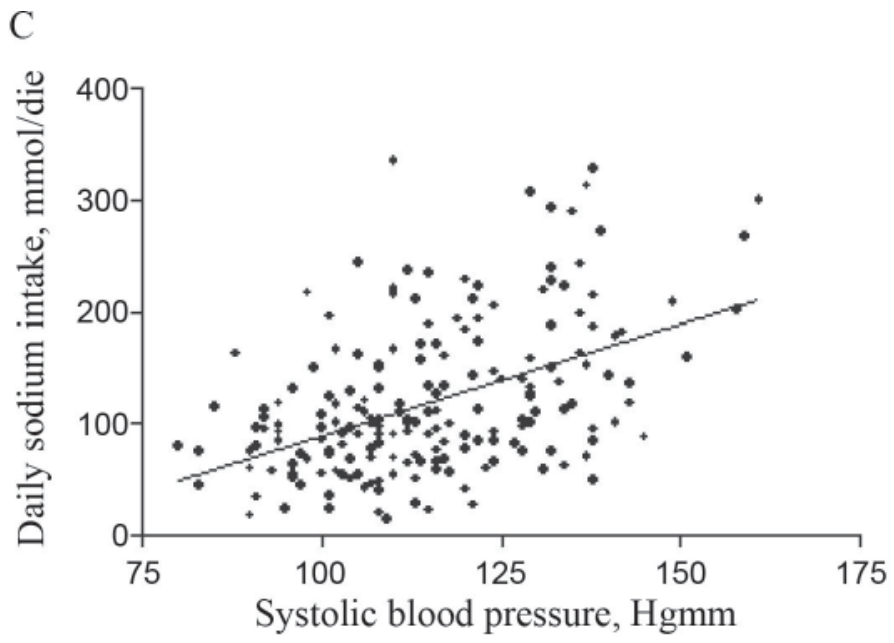

Fig. 1C. Correlation between daily sodium intake and systolic blood pressure in the total study population (n: $200, \mathrm{r}^{2}=0.204,95 \%$ CI: 1.446 to $2.543, \mathrm{P}<0.0001$ ).

Similarly, potassium intake positively correlated with age, BMI, and systolic blood pressure (Fig. 2).

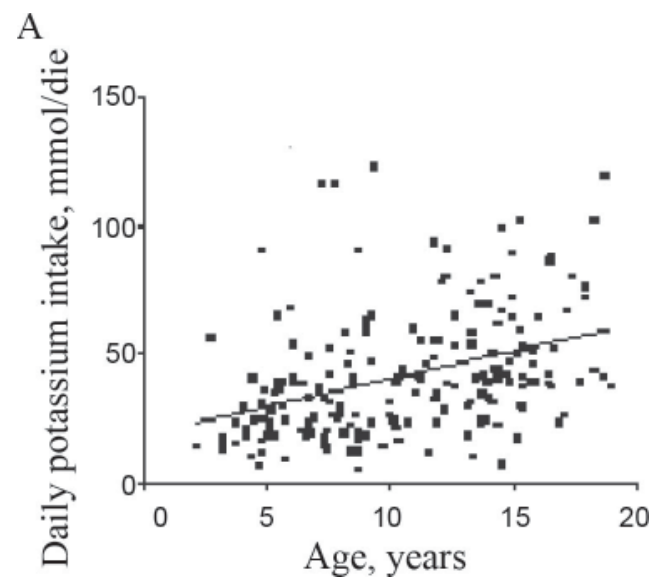

Fig. 2A. Positive correlation between daily potassium intake and age (n: $200, \mathrm{r}^{2}=0.147,95 \%$ CI: 1.435 to $2.881, \mathrm{P}<0.0001$ ). 


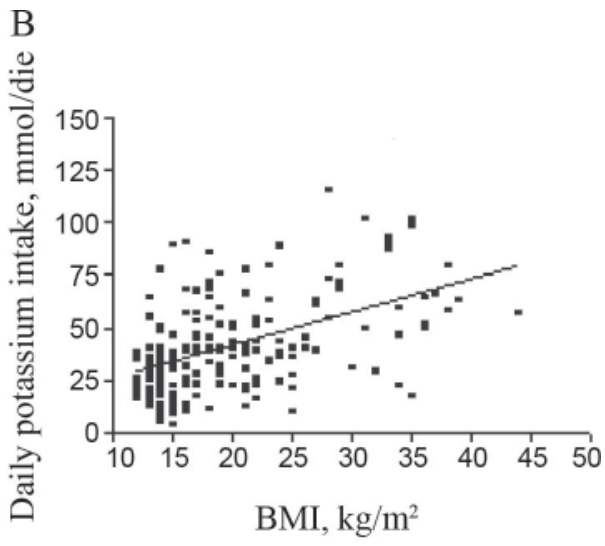

Fig. 2B. Linear regression analysis of daily potassium intake and BMI (n: $200, \mathrm{r}^{2}=0.199,95 \%$ CI: 1.124 to $1.994, \mathrm{P}<0.0001$ )

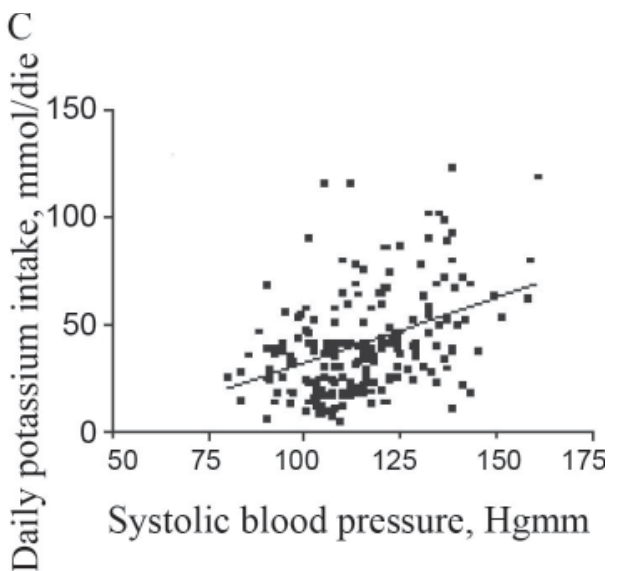

Fig. 2C. Correlation between daily potassium intake and systolic blood pressure in the total population studied (n: $200, \mathrm{r}^{2}=0.165,95 \%$ CI: 1.325 to $2.446, \mathrm{P}<0.0001$ ).

The mean value of sodium intake increased steadily with age. These sodium intakes considerably exceeded the Adequate Intakes (AI) in each group above 4 years of age. AI may be used as a goal for individual intake, and it is believed to cover the need of individuals of those age groups. The maximum level of daily sodium intake that is likely to pose no risk of adverse effects is about $150 \%$ of AI (USDA, 2009). Between 1990 and 2010, the sodium intake increased about $25 \%$ between $1-8$ years, but did not change in the 9-18 year age group 
(Table 2). The potassium intake was only a third of the AI among 1-8 year old children, and only about $40 \%$ of the AI among 9-18 year olds. Over the last 20 years, the potassium intake increased about $250 \%$ in $1-3$ year olds, about $200 \%$ in $4-13$ year olds, and about $150 \%$ in 14-18 year olds (Table 2).

\begin{tabular}{lcccc}
\multicolumn{5}{c}{ Table 2. Comparison of the daily sodium and potassium intake of Hungarian children and adolescents with } \\
recommended values
\end{tabular}

The daily sodium and potassium intakes (corrected for 24-h urine excretion) are expressed as mean and SD in the different age groups. The reference values (Adequate Intakes) are adapted from the DRI reports ( $1 \mathrm{mmol}$ sodium=23 $\mathrm{mg}$ sodium, $1 \mathrm{mmol}$ potassium=39 $\mathrm{mg}$ potassium).

Daily sodium excretion expressed per kg body weight decreased progressively with age $\left(\mathrm{r}^{2}=0.102, \mathrm{P}<0.0001\right)$, and no discernible difference could be detected between girls (mean \pm SD: $3.0 \pm 1.5 \mathrm{mmol} / \mathrm{kg} / \mathrm{die}$ ) and boys (mean \pm SD: $3.3 \pm 2.2 \mathrm{mmol} / \mathrm{kg} / \mathrm{die})(\mathrm{P}=0.22)$. Daily potassium intake expressed per kg body weight also declined steadily with age $\left(r^{2}=0.169, P<0.0001\right)$ (Fig. 3), and there was no significant difference between girls (mean \pm SD: $1.1 \pm 0.7 \mathrm{mmol} / \mathrm{kg} / \mathrm{die})$ and boys (mean $\pm \mathrm{SD}: 1.2 \pm 0.8 \mathrm{mmol} / \mathrm{kg} / \mathrm{die})(\mathrm{P}=0.88)$. 


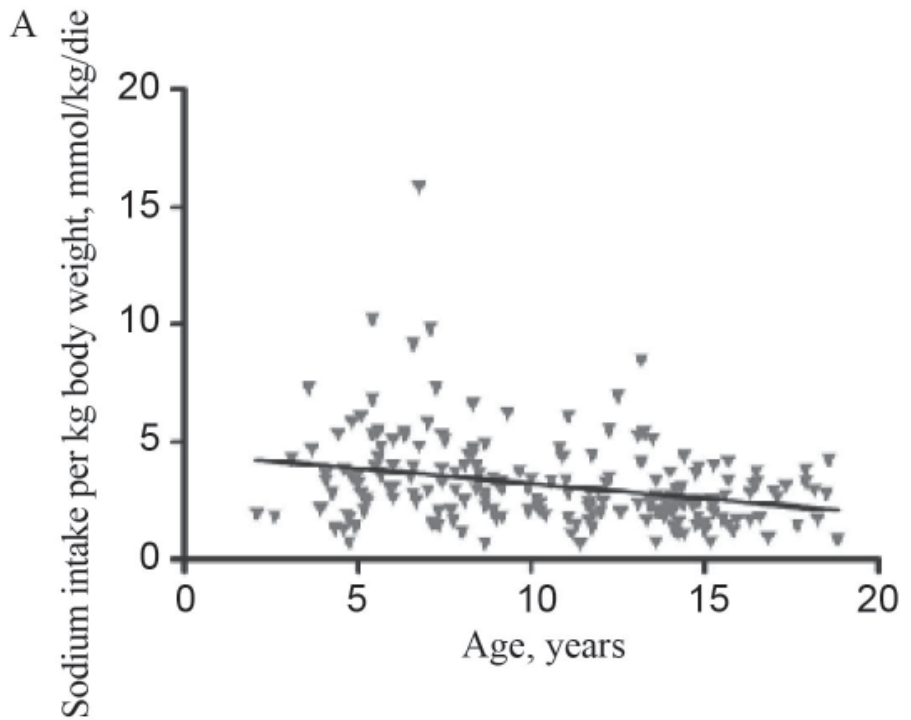

Fig. 3A. Linear regression analysis of daily sodium intake expressed per $\mathrm{kg}$ body weight and age (n: $200, \mathrm{r}^{2}=0.102,95 \%$ CI: -0.201 to $-0.083, \mathrm{P}<0.0001$ ).

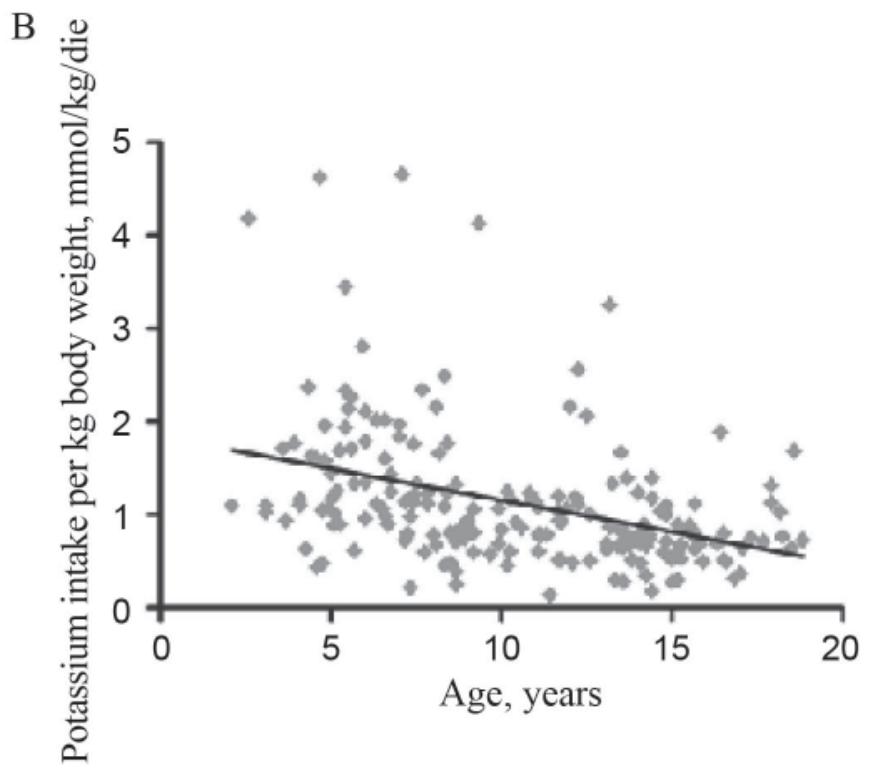

Fig. 3B. Correlation between daily potassium intake expressed per $\mathrm{kg}$ body weight and age (n: $200, \mathrm{r}^{2}=0.169,95 \% \mathrm{CI}:-0.093$ to $-0.049, \mathrm{P}<0.0001$ ).

As a result of the parallel trend and time course of urinary sodium and potassium excretion, the sodium to potassium ratio remained practically unchanged and amounted to a value as high as $3.2 \pm 1.6 \mathrm{mmol} / \mathrm{mmol}$ over the age range studied. This ratio exceeded three Acta Alimentaria 44, 2015 
times the recommended $1: 1$ value, but it proved to be only $20-40 \%$ of the value we found in 1990 (Table 3). We did not find significant differences in the sodium to potassium ratios between hypertensive and normotensive, or obese and non-obese children (Fig. 4).

Table 3. The comparison of the sodium to potassium ratio measured in 2008-2010, to those of 1990

\begin{tabular}{lccc}
\hline Years of the study & Age groups (years) & $\begin{array}{c}\text { Number of cases } \\
\begin{array}{c}\text { Sodium to potassium } \\
\text { ratio (mmol/mmol) } \\
\text { mean } \pm \text { SD }\end{array}\end{array}$ \\
\hline 1990 & $1-3$ & 21 & $4.6 \pm 1.3$ \\
& $4-8$ & 57 & $3.9 \pm 1.1$ \\
& $14-18$ & 53 & $4.2 \pm 1.2$ \\
$2008-2010$ & $1-3$ & 48 & $4.3 \pm 1.0$ \\
& $4-8$ & 7 & $2.9 \pm 1.6$ \\
& $9-13$ & 77 & $3.2 \pm 1.3$ \\
$14-18$ & 62 & $3.2 \pm 0.9$ \\
\hline
\end{tabular}

A

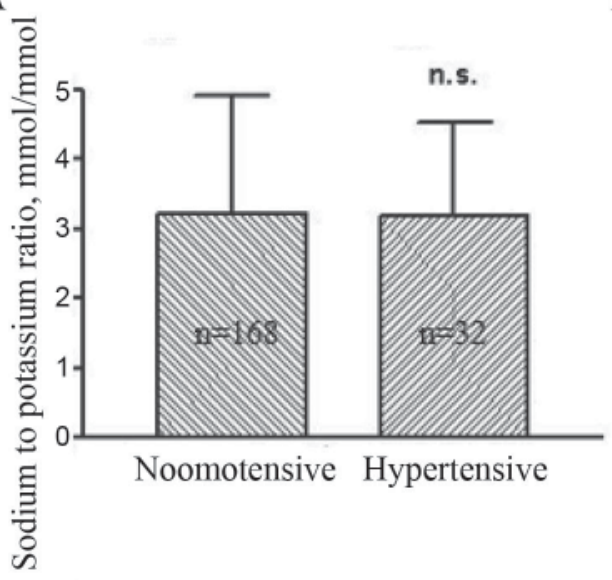

B

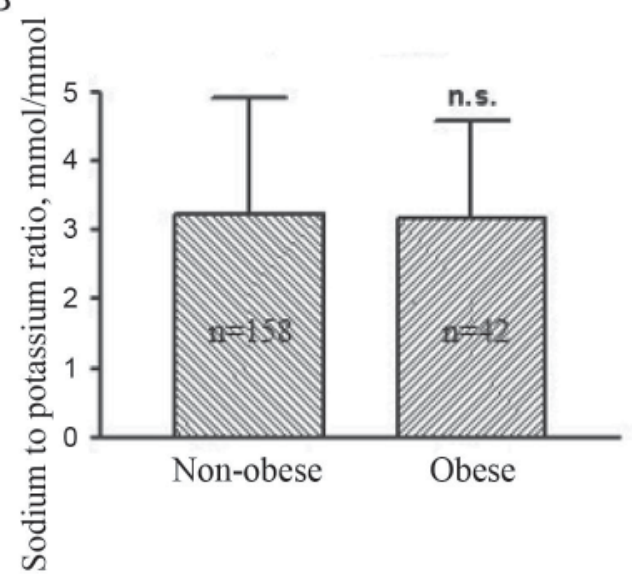

Fig. 4. Difference of sodium to potassium ratio in normotensive and hypertensive (mean \pm SD: $3.2 \pm 1.6 \mathrm{mmol} / \mathrm{mmol}$ and $3.1 \pm 1.3 \mathrm{mmol} / \mathrm{mmol}, \mathrm{n} . \mathrm{s}$.$) , or non-obese and obese children$ (mean \pm SD: $3.2 \pm 1.7$ and $3.1 \pm 1.4 \mathrm{mmol} / \mathrm{mmol}$, n.s.).

When adjustment was made for BMI, gender, and age, using multivariate regression analysis, the systolic blood pressure proved to be independent of urinary sodium excretion and of daily potassium intake.

The present study shows that unselected Hungarian children and adolescents between 1-18 years of age, on a traditional Hungarian diet, had much higher daily sodium intake and 
lower daily potassium intake than the AI. On the one hand, this could be explained by the high salt content of processed food and cafeteria meals (MARTOs, 2010), and on the other hand, by the low fruit and vegetable consumption of children in Hungary.

The strength of the study is that the scope of the data compared covers 20 years. Comparing the results from 1990 with our latest data, we can say that a positive tendency can be detected, as sodium intake remained practically unchanged and potassium intake showed a significant increase. Due to these trends the sodium to potassium ratio, the most important risk factor for hypertension decreased in the last 20 years. The major limitation of our study is the small sample size. It is to be stressed, however, that high sodium intake in childhood and adolescence may have long-term impact on the establishment of salt preference, and on the development of hypertension and related diseases later in life.

\section{Conclusions}

Our study demonstrated that Hungarian children and adolescents have unfavourable sodium to potassium ratio in their diet. Therefore, we must join the global efforts to implement prevention programs advising low sodium - high potassium diet at as early an age as possible. Such programs are likely to reduce the level of blood pressure (ELLISON et al., 1989; YANG et al., 2012), the incremental rise in blood pressure with age, and the prevalence of hypertension and related morbidity and mortality later in life.

We thank S. JEGES and Z. NyUL, who helped in the statistical analysis of data, and A. SóLYOM, who made grammatical revision.

\section{References}

Biró, L., Regöly-Mérei, A., Nagy, K., Péter, S., Arató, G., Szabó, C., Martos, E. \& Antal, M. (2007): Dietary habits of school children: representative survey in metropolitan elemetary schools. Part two. Ann. Nutr. Metab., 51, 454-460.

Brion, M.J., Ness, A.R., Davey Smith, G., Emmett, P., Rogers, I., Whincup, P. \& Lawlor, D.A. (2008): Sodium intake in infancy and blood pressure at 7 years: findings from the Avon Longitudinal Study of Parents and Children. Eur. J. Clin. Nutr., 62, 1162-1169.

D.M.D.B. (2011): European detailed mortality database. Copenhagen, WHO Regional Office for Europe, Available at http://data.euro.who.int/dmdb (last accessed 10 September 2013).

Ellison, R.C., Capper, A.L., Stephenson, W.P., Goldberg, R.J., Hosmer, D.W. Jr, Humphrey, K.F., Ockene, J.K., Gamble, W.J., Witschi, J.C. \& Stare, F.J. (1989): Effects on blood pressure of a decrease in sodium use in institutional food preparation: the Exeter-Andover Project. J. Clin. Epidemiol., 42, 201-208.

Frohlich, E.D. (2007): The salt conundrum: a hypothesis. Hypertension, 50, 161-166.

Geleijnse, J.M., Hofman, A., Witteman, J.C., Hazebroek, A.A., Valkenburg, H.A. \& Grobbee, D.E. (1997): Longterm effects of neonatal sodium restriction on blood pressure. Hypertension, 29, 913-917.

Gibson, R.S. (2005): Principles of nutritional assessment. Oxford University Press, New York, pp. $246-252$.

GYÖRKE, Zs. (1990): Összefüggés a sóbevitel és a 24 órás elektrolitürítés között gyermekkorban (Relationship between salt intake and urinary electrolyte excretion over a 24 hour period in children.) Orv. Hetil., 131, 2711-2714.

Hanevold, C.D. (2013): Sodium intake and blood pressure in children. Curr. Hypertension Rep., 15, 417-425. 
Joubert, K., Darvay, S. \& Ágfalvi, R. (2006): Child growth national longitudinal study from birth to 18 years of age. Hungarian Central Statistical Office, Demographic Research Institute - Budapest. Available at http:// www.demografia.hu/letoltes/kiadvanyok/Kutjelek/Kutjel83_honlapra.pdf (last accessed 10 September 2013).

Kesteloot, H., Tzoulaki, I., Brown, I.J., Chan, Q., Wijeyeserera, A., Ueshima, H., Zhao, L., Dyer, A.R., Unwin, R.J., StAmler, J. \& ElLiott, P. (2011): Relation of urinary calcium and magnesium excretion to blood pressure: The international study of macro- and micro-nutrients and blood pressure and the international cooperative study on salt, other factors, and blood pressure. Am. J. Epidemiol., 174, 44-51.

Kristbjornsdottir, O.K., Halldorsson, T.I., ThorsdottiR, I. \& Gunnarsdottir, I. (2012): Association between 24hour urine sodium and potassium excretion and diet in six-year-old children: a cross sectional study. Nutr. J., $11,94$.

Martos, E. (2010): Európai összefogás a lakosság sóbevitelének csökkentése érdekében - Nemzeti Sócsökkentő Program (European cooperation to reduce the salt intake of the population. National Salt Reducing Program). Metabolizmus, 8, 23-24.

N.H.B.P.E.P. (2004): National High Blood Pressure Education Program Working Group on High Blood Pressure in Children and Adolescents. The fourth report on the diagnosis, evaluation, and treatment of high blood pressure in children and adolescents. Pediatrics, 114, 555-576.

Ovesen, L. \& Boeing, H.; Efcosum Group (2002): The use of biomarkers in multicentric studies with particular consideration of iodine, sodium, iron, folate and vitamin D. Eur. J. Clin. Nutr., 56 Suppl 2, 12-17.

Reinivuo, H., Valsta, L.M., Laatikainen, T., Tuomilehto, J. \& Pietinen, P. (2006): Sodium in the Finnish diet: II trends in dietary sodium intake and comparison between intake and 24-h excretion of sodium. Eur. J. Clin. Nutr., 60, 1160-1167.

Sacks, F.M., Svetkey, L.P., Vollmer, W.M., Appel, L.J., Bray, G.A., Harsha, D., Obarzanek, E., Conlin, P.R., Miller, E.R. 3Rd, Simons-Morton, D.G., Karanja N. \& Lin, P.H.; Dash-Sodium Collaborative Research Group (2001): Effects on blood pressure of reduced dietary sodium and the Dietary Approaches to Stop Hypertension (DASH) diet. DASH-Sodium Collaborative Research Group. N. Engl. J. Med., 344, 3-10.

Shirazki, A., Weintraub, Z., Reich, D., Gershon, E. \& Leshem, M. (2007): Lowest neonatal serum sodium predicts sodium intake in low birth weight children. Am. J. Physiol. Regul. Integr. Comp. Physiol., 292, 1683-1689.

Strazzulo, P., D’elia, L., Kandala, N.B. \& Cappuccio, F.P. (2009): Salt intake, stroke, and cardiovascular disease: meta-analysis of prospective studies. BMJ, 339, b4567.

Tasevska, N., Runswick, S.A. \& Bingham, S.A. (2006): Urinary potassium is as reliable as urinary nitrogen for use as a recovery biomarker in dietary studies of free living individuals. J. Nutr., 136, 1334-1340.

USDA (2009): United States Department of Agriculture, National Agricultural Library, Available at http://fnic.nal. usda.gov/dietary-guidance/dietary-reference-intakes (last accessed 12 February 2013).

Yang, Q., Liu, T., Kuklina, E.V., Flanders, W.D., Hong, Y., Gillespie, C., Chang, M.H., Gwinn, M., Dowling, N., Khoury, M.J. \& Hu, F.B. (2011): Sodium and potassium intake and mortality among us adults: Prospective data from the Third National Health and Nutrition Examination Survey. Arch. Intern. Med., 171, 1183-1191.

Yang, Q., Zhang, Z., Kuklina, E.V., Fang, J., Ayala, C., Hong, Y., Loustalot, F., Dai, S., Gunn, J.P., Tian, N., Cogswell, M.E. \& Merritt, R. (2012): Sodium intake and blood pressure among US children and adolescents. Pediatrics, 130, 611-619. 